\title{
EFFECT OF CHARCOAL -ENRICHED SUBSTRATE ON SEEDLINGS OF RHIZOBIUM-INOCULATED LEGUME TREES ${ }^{1}$
}

Aroldo Felipe de Freitas ${ }^{2 *}$, Luiz Augusto Gomes de Souza ${ }^{3}$, Irene Maria Cardoso ${ }^{4}$ and Nelson Venturin ${ }^{5}$

${ }^{1}$ Received on 24.10.2013 accepted for publication on 24.10.2016.

${ }^{2}$ Instituto Nacional de Pesquisas da Amazônia, Programa de Pós-Graduação em Ciências de Florestas Tropicais, Manaus, Amazonas, Brasil. E-mail:<afelipefreitas@yahoo.com.br>.

${ }^{3}$ Instituto Nacional de Pesquisas da Amazônia, Manaus, AM - Brasil. E-mail: <souzalag@inpa.gov.br>.

${ }^{4}$ Universidade Federal de Viçosa, Departamento de Solos, Viçosa, MG - Brasil. E-mail: <irene@ufv.br>.

${ }^{5}$ Universidade Federal de Lavras, Departamento de Ciências Florestais, Lavras, MG - Brasil. E-mail: <venturin@dcf.ufla.br>.

*Corresponding author.

\begin{abstract}
Native legume trees are planted in agroforestry systems for their hardiness and symbiosis with soil bacteria of the genus rhizobium, efficient in N2 fixation. The enrichment of the substrate composition with fine charcoal for seedling production of these trees is interesting for increasing soil porosity, water retention and the proliferation of beneficial microorganisms. Experiments were carried out to analyze the effect of substrate enrichment with charcoal on the quality of Clitoria fairchildiana, Enterolobium schomburgkii and Inga edulis seedlings. The treatments consisted of a 3:2:0.5 (v:v) mixture of clay soil, sand and bovine manure and a 3:2 (v:v) mixture of clay soil and sand combined with charcoal rates of 0, 10, 19 and 29\%. After mixing the components, substrate samples were collected and chemically analyzed. The experiment was arranged in a completely randomized design with 5 treatments and 10 replications. The seedlings were inoculated with homologues rhizobia and growth controlled monthly. The plants were collected to determine the number of nodules and dry biomass of roots, shoots and nodules. Seedling growth was similar on substrates containing charcoal or manure, except for E. schomburkii, which increased by more than $100 \%$ on the charcoal-containing substrates. The number and dry biomass of nodules in the charcoal-containing substrates was up to $100 \%$ and $300 \%$ higher than in the manure-containing treatment, respectively. The results indicated that the substitution of manure by charcoal favors the seedling quality of the studied species.
\end{abstract}

Keywords: Inga edulis; Enterolobium schomburgkii; Clitoria fairchildiana

\section{ADIÇÃO DE CARVÃO NO SUBSTRATO DE FORMAÇÃO DE MUDAS DE LEGUMINOSAS ARBÓREAS INOCULADAS COM RIZÓBIOS}

\begin{abstract}
RESUMO-O estabelecimento do plantio florestal com mudas bem noduladas favorece o seu crescimento inicial e sobrevivência após a fase de estabelecimento. As espécies leguminosas arbóreas ingá (Inga edulis), orelhade-macaco (Enterolobium schomburgkii) e palheteira (Clitoria fairchildiana) têm sido recomendadas para recuperação de áreas degradadas e composição de sistemas agroflorestais pela sua rusticidade e capacidade de estabelecer simbiose com bactérias do solo do grupo dos rizóbios, eficientes em fixar $N_{2}$. Foi conduzido estudo experimental para analisar o efeito da adição de carvão vegetal em mistura substrato sobre a qualidade de mudas produzidas em viveiro. Os tratamentos utilizados foram: mistura 3:2:0,5 (v:v) de solo argiloso, areia e esterco bovino e de solo argiloso e areia 3:2 (v:v), combinado com carvão vegetal em dosagem de 0,10 , 19 e $29 \%$ de carvão em mistura. Amostras das misturas substratos foram coletadas e analisadas quimicamente. O delineamento foi o inteiramente casualizado com cinco tratamentos e dez repetições. As mudas foram inoculadas com estirpes homólogas de rizóbios, sendo que $5 \mathrm{~mL}_{\text {planta }}{ }^{-1}$ foram aplicados na base do coleto das mudas. O crescimento das mudas foi acompanhado mensalmente e as plantas foram coletadas para contagem do número
\end{abstract}


de nódulos formados e determinação da biomassa das raízes, parte aérea e nódulos após secagem a $65^{\circ} \mathrm{C} /$ 72 h. O uso de esterco na composição dos substratos inibiu a nodulação em todas as três espécies estudadas. Foi também possivel verificar aumento na qualidade das mudas pelo uso de carvão no substrato.

Palavras-chave: Inga edulis; Enterolobium schomburgkii; Clitoria fairchildiana.

\section{INTRODUCTION}

The production of high-quality seedlings is a prerequisite for the success of forest enterprises (CUNHA et al., 2006). Biometric characteristics and other indicators can be used in the final phase of seedling production to evaluate the quality and moment when the plantlets are ready for the final planting, eliminating those without vigor (FONSECA etal., 2002). Among the most commonly used indicators of seedling quality are biomass, stem length or diameter, stem flexibility, and height/diameter and shoot/root ratios, Dickson Quality Index and leaf area (GOMES; PAIVA, 2006).

A goal of forestry research is the establishment of quality indicators for the most important species. To this end, the Dickson Quality Index (DQI) (DICKSON et al., 1960) serves as a supports for a more holistic interpretation of the research results of seedling production, by condensing various quality indicators in a single index of easy interpretation. The higher the value of this index, the higher is the seedling quality (FONSECA et al., 2002). However, this index must be calculated specifically for each species of interest.

Ice-cream-bean (Inga edulis), orelha-de-macaco (Enterolobium schomburgkii) and palheteira (Clitoria fairchildiana) are promising legume tree species for agroforestry, in view of their capacity to fix atmospheric $\mathrm{N}$ in a symbiotic relationship with bacteria and of their rapid growth, even under adverse conditions. Palheteira has been used for urban afforestation and recovery of degraded areas due to its leafy canopy and beautiful flowers. Orelha-de-macaco is also interesting because of its high-density wood, with good mechanical strength and moderate durability. Orelha-de-macaco is indicated as veneer wood, for the construction of car bodies, timber flooring, and for external constructions. Icecream-bean wood is used for boxes, firewood and charcoal and the flavor of its fruits is highly appreciated by the populations of the Amazon region, where it is grown in backyards and sold on open markets (LORENZI, 2002).
To grow high-quality seedlings of these species, the required inputs must be readily available and cheap (BERNARDINO et al., 2005; CUNHA et al., 2006), if possible based on recyclable by-products such as charcoal residues. The use of charcoal powder can contribute to the economic viability of seedling production, for being a cheap by-product, a residue of the selection of larger charcoal for the market.

Charcoal is present in the anthropogenic eutrophic soil classified as Terra Preta de Índio, contributing to the improvement of the soil physical properties by the formation of organic matter more resistant to microbial digestion. Consequently, charcoal is one of the factors that maintains the fertility of this soil class after consecutive crops (GLASER et al., 2001; MAJOR et al., 2005; MOREIRA, 2007). The effect of the addition of fine wood charcoal to the soil, also known as "charcoal powder", has been studied recently in Brazil for improving soil properties, especially for increasing the proliferation of beneficial microorganisms, as those with capacity to fix atmospheric $\mathrm{N}$ in symbiosis with legumes (ZANETTI et al., 2003; RONDON et al., 2007; STEINER et al., 2008).

The use of wood charcoal in the development of forest seedlings has not yet been investigated, especially for legume trees. This research was developed to evaluate the effect of the enrichment of substrate mixtures with fine charcoal at different rates on the growth, nodulation and efficiency of symbiotic $\mathrm{N}_{2}$ fixation of seedlings of Clitoria fairchildiana, Enterolobium schomburgkii and Inga edulis.

\section{METHODOLOGY}

\subsection{Description of the experiment}

The experiments were conducted in 2011 and 2012 on the Campus INPA V-8 in areas of seedbeds and greenhouses of the Coordination of Society, Environment and Health of the National Research Institute of the Amazon (CSAS-INPA), in Manaus, Amazonas (AM), Brazil. According to Köppen, the climate of Manaus is classified as Afi - tropical rainy, with annual means of $2,325 \mathrm{~mm}$ rainfall, temperature $26.6^{\circ} \mathrm{C}$ and relative humidity between 84 and 90\% (INPE, 2003). 
The area of seed beds consisted of wooden benches arranged in a laterally open shed covered with clay tiles. The structure of this greenhouse consisted of iron and was covered with shade net, with $50 \%$ light incidence, open sides, a cemented floor, an area of $8 \times 11 \mathrm{~m}$, and irrigation was applied through plastic hoses.

Seeds of ice-cream-bean (Inga edulis Mart, Mimosoideae) and palheteira (Clitoria fairchildiana R.A. Howard, Faboideae) were harvested from mother trees at the Experimental Station of Tropical Forestry of INPA (BR 174, km 46, Manaus, AM, Brazil). Seeds of orelha-de-macaco (Enterolobium schomburgkii Benth, Mimosoideae) were collected in Codajás, AM. Each species was evaluated in an experiment.

The fruits of ice-cream-bean were harvested directly from the tree canopy with a curved knife on an extralong rod. The fruits of palheteira and orelha-de-macaco were collected under the canopy of the matrices in the peak phase of seed dispersal by barochory. After air-drying for $48 \mathrm{~h}$, the fruits were processed to obtain pure seed at the INPA Soil Microbiology Laboratory.

Prior to sowing, the seeds of the three species were soaked in water for $24 \mathrm{~h}$ to promote imbibition. The orelha-de-macaco seeds underwent a pre-germination treatment consisting of cutting the tegument with tweezers on the far end of the embryo, while ice-creambean and palheteira seeds were not subjected to any pre-germination treatment apart from imbibition. One hundred and fifty ice-cream-bean and orelha-de-macaco seeds were sown in rows, using drained plastic boxes $(40 \times 80 \times 15 \mathrm{~cm})$ filled with washed sand. The seedlings were watered daily in the germination phase. When most of the seeds had germinated and grown a definite pair of leaves, 100 seedlings of similar size per species were transplanted to the substrates. For palheteira, three seeds per unit were sown directly in the bags already filled with the substrate mixtures, followed by thinning, sparing the most vigorous and most central plantlets.
The components of the substrate mixtures were clay soil, bovine manure, sand, and fine charcoal. The clay soil and the tanned bovine manure were collected on an experimental farm of the Federal University of Amazonas(UFAM), BR 174, Km 35, Manaus, AM. Yellow Latosol/Latossolo Amarelo soil was sampled to a depth of $10 \mathrm{~cm}$ in an area of abandoned pasture to ensure a higher quantity of native rhizobium inoculum (VIEIRA et al., 2011). Sand, classified as construction material, was purchased in Manaus. Fine charcoal, a byproduct of tree burning, was purchased from an authorized rural producer, licensed by the environmental agency, at BR 174, Ramal ZF-1, in the Community Nova Canaã, municipality of Manaus. This fine charcoal was composed of a mixture of wood of several species during charcoal production. This type of material is available on the market and was therefore used in the experiment, since this study was intended to represent the conditions for producers as close to reality as possible.

Each component was dried in the shade for $48 \mathrm{~h}$ and then sieved ( $5 \mathrm{~mm}$ mesh). The mixtures were prepared on a volumetric basis. The 3:2:0.5 (v:v) substrate mixture of clay soil, sand and bovine manure proposed for noduliferous legume trees (SOUZA, 2007) was chosen as control treatment. This allowed a comparison of the results with the quality of a scientifically proven substrate. The proportion of charcoal used in the treatments was estimated to meet the recommended application of $0,40,80$, and $120 \mathrm{tha}^{-1}$ of charcoal tested under field conditions by OLIVEIRA et al. (2010). The applied treatments were described in Table 1.

\subsection{Seedling cultivation}

Samples of the isolated components and substrate mixtures were collected for laboratory analysis prior to sowing. After homogenization, the substrates were distributed in polypropene plastic bags $(13 \times 27 \mathrm{~cm})$, properly drained, with a diameter of $11 \mathrm{~cm}$ after filling and volume of $2 \mathrm{~kg}$. The seedlings were transplanted

Table 1 - Proportions of substrate mixtures used for the production of leguminous seedlings.

Tabela 1 - Proporções das misturas substrato utilizadas na formação de mudas leguminosas arbóreas.

\begin{tabular}{ccc}
\hline Treatment & Substrate mixture & Label \\
\hline T 1 & $3: 2: 0.5$, clay soil, sand and cattle manure & $\mathrm{S}_{\mathrm{e}}$ \\
T 2 & $3: 2$, clay soil and sand & $\mathrm{S}$ \\
T 3 & $5.5: 3.5: 1$, clay soil, sand and charcoal & $\mathrm{S}_{1 \mathrm{c}}$ \\
T 4 & $2.5: 2: 1$, clay soil, sand and charcoal & $\mathrm{S}_{2 \mathrm{c}}$ \\
T 5 & $5: 2: 1$, clay soil, sand and charcoal & $\mathrm{S}_{3 \mathrm{c}}$ \\
\hline
\end{tabular}


by the technique of naked roots after growing one pair of definitive leaves, in the case of ice-cream-bean and orelha-de-macaco. During the experiment, the substrates were irrigated regularly on days without rain and when necessary weeds were removed by hand.

The height and diameter of the root collar of icecream-bean and orelha-de-macaco seedlings were first measured one day after transplanting. The plant height was defined as the distance between the root collar and apical meristem of the plantlet. For palheteira, which was sown directly in the bags, growth measurement and thinning were first carried out after 19 days. From then on, the seedlings were measured monthly until harvest.

The seedlings were inoculated with strains of homologous rhizobia, preserved in the rhizobium collection of the Laboratory of Soil Microbiology of INPA. For this purpose, liquid YM inoculant (HUNGRIA et al., 1994), pH 6.0, without dye, was distributed in $125 \mathrm{~mL}$ Erlenmeyer flasks and incubated for eight days on a mechanical stirrer. When no selected strains for local soils were available, the strains were combined in a cocktail, as follows: for ice-cream-bean, strains SMS 828, SMS 832, SMS 841, SMS 842, SMS 847, and SMS 850, for orelha-de-macaco, strains SMS 600, SMS 602, and SMS 617, and for palheteira, strains SMS 938, SMS 941, SMS 943, SMS 944, SMS 945, SMS 949, SMS 950, and SMS 959. The seedlings were treated with $5 \mathrm{~mL}$ of liquid inoculant applied at the stem base, 21 and 32 days after transplanting of ice-cream bean and orelha-de-macaco, and 27 days after germination of palheteira.

\subsection{Harvesting of seedlings and laboratory analysis}

The seedlings were harvested when the quality was sufficient for the final planting, i.e., 92 and 75 days after transplanting for ice-cream-bean and orelha-demacaco, respectively, and 90 days after sowing for palheteira. On this occasion, the height and diameter of the root collar of the seedlings were measured and the whole plants were extracted after crumbling the substrate. Then they were washed and cut in shoots and roots. The nodules were detached from the roots, counted and separated. All of the plant material was oven-dried at $65^{\circ} \mathrm{C}$ for $72 \mathrm{~h}$, and weighed. For the shoots, the stem biomass was also determined and the leaf biomass calculated by subtraction.
The dried leaf material was ground in a knife mill and prepared to determine the $\mathrm{N}$ tissue concentration by acid digestion of the samples with sulfuric acid, by the modified Kjeldahl method. From the leaf N concentration, the total $\mathrm{N}$ content of the leaves was calculated.

The leaf $\mathrm{N}$ content and chemical properties of the isolated components and substrate mixtures were determined at the Thematic Laboratory of Soils and Plants - LTSP/INPA, in Manaus, AM. The $\mathrm{pH}$ of the substrates in water $(1: 2.5)$ and $\mathrm{Ca}, \mathrm{Mg}$ and $\mathrm{Al}$ contents were determined in $1 \mathrm{~N} \mathrm{KCl}$ extraction solution (EMBRAPA, 1997). The C content was determined by the Walkley-Black method (MENDONÇA; SILVA, 2001) and the organic matter content estimated from the $\mathrm{C}$ content (C content $x$ 1.72). Potassium was determined by flame photometry, $\mathrm{P}$ extracted and determined by spectrophotometry, and $\mathrm{Zn}$ and Fe were extracted in Mehlich-1 solution and quantified in atomic-absorption readings.

The dried leaf material was ground in a knife mill and prepared to determine $\mathrm{N}$ concentration in the tissue. To this end, the samples were acid-digested with sulfuric acid by the modified Kjehdal method. The leaf $\mathrm{N}$ values were multiplied by the shoot dry weight to calculate cumulative $\mathrm{N}$ in the shoot.

\subsection{Data analysis and experimental design}

From the above results, the ratio of Shoot Dry Weight/Root Dry Weight (SDW/RDW) was calculated. The Dickson Quality Index (DQI) (DICKSON et al., 1960) was also determined by the formula:

$$
\mathrm{DQI}=[\mathrm{H}(\mathrm{cm}) / \mathrm{D}(\mathrm{mm})]+[\mathrm{TDW}(\mathrm{g})
$$

where TDW is the total dry matter, $H$ the plant height, D the root collar diameter, SDW the shoot dry weight, and RDW the root dry weight.

For all tree species, the experimental design was completely randomized, with 5 treatments and 10 replications for measurements of growth and biomass and 5 replications for analyses of leaf $\mathrm{N}$ contents. For the analysis, the number and dry biomass of the nodules were transformed with $\mathcal{V}_{(\mathrm{x}+0.01)}$, and the leaf $\mathrm{N}$ content and cumulative shoot $\mathrm{N}$ content with arc sine $\left(\mathrm{V}_{(\mathrm{x}+0.01)}\right.$, as recommended by Centeno (1990). The results were 
analyzed using software Estat, developed by UNESP, version 2002 and the means compared by Tukey's test at a probability of $5 \%$.

\section{RESULTS}

Important differences were observed between the chemical characteristics of the components and the substrate mixtures (Table 2). The $\mathrm{pH}$ of charcoal was the lowest, followed by the $\mathrm{pH}$ of clay soil, manure and sand.

The tested substrates did not affect the growth parameters, SDW/RDW ratio, and DQI of ice-cream bean and palheteira, but had a significant influence $(\mathrm{P}<0.05)$ on the development of orelha-de-macaco seedlings (Table 3 ). Ice-cream bean and palheteira needed a period of about 90 days in the greenhouse to reach a plant height of $30 \mathrm{~cm}$, whereas 175 days after thinning, orelha-de-macaco had not reached a height of $20 \mathrm{~cm}$ in most of the substrates.

The experimental data indicated the worst performance of orelha-de-macaco seedlings when grown in the 3:2:0.5 mixture of clay soil, sand and cattle manure $\left(\mathrm{S}_{\mathrm{e}}\right.$ (Table 3). On the substrates with charcoal and on the 3:2 clay soil and sand mixture $(\mathrm{S})$, orelha-de-macaco plants had significantly taller heights and a greater biomass of dry roots $(\mathrm{P}<0.05)$ than those grown in $\mathrm{S}_{\mathrm{e}}$. The increase in root collar diameter of orelha-demacaco seedlings was also significantly affected in response to the substrate mixtures. In this case, the largest root collar diameter was verified in the mixture $\mathrm{S}$, significantly larger than measured in the mixture of 1.5:2:1 clay soil, sand and charcoal $\left(\mathrm{S}_{3 c}\right)$ and $\mathrm{S}_{\mathrm{e}}$.

The measures of shoot and root growth of orelhade-macaco were also significantly affected by the substrate used. For root growth, as mentioned above, the mixture $\mathrm{S}_{\mathrm{e}}$ was not beneficial for the species. For shoot biomass, the plants grown in mixture $\mathrm{S}$ were significantly superior to those grown in $\mathrm{S}_{\mathrm{e}}$ and in the 5.5:3.5:1 mixture of clay soil, sand and charcoal $\left(\mathrm{S}_{1 \mathrm{c}}\right)$.

The lowest and most balanced SDW/RDW ratio of orelha-de-macaco plants was 1.48 in the substrate mixture $\mathrm{S}_{1 \mathrm{c}}$, where the shoot diameter and dry matter were also highest. For the DQI of orelha-de-macaco seedlings, was around 0.30 in all treatments with charcoal, being more than three times higher and statistically different from $\mathrm{S}_{\mathrm{e}}$ with a DQI of 0.08 .

For being nodular legume and $\mathrm{N}_{2}$-fixing trees, the effect of charcoal in the substrate mixture is not only reflected in plant growth data, but also expressed in the nodulation characteristics and $\mathrm{N}$ uptake by the seedlings. In this sense, the experimental results indicated a significant effect of the substrates on nodulation characteristics of the three studied legume tree species (Table 4). On the other hand, considering the $\mathrm{N}$ uptake by the leaf $\mathrm{N}$ contents and shoot $\mathrm{N}$ accumulation, only ice-cream-bean was irresponsive to the different substrate mixtures, absorbing $\mathrm{N}$ efficiently in all tested combinations.

Table 2 - Chemical characteristics of the separate components and substrate mixtures used for the production of leguminous seedlings.

Tabela 2 - Características químicas dos componentes isolados e das misturas substrato empregadas na formação de mudas leguminosas arbóreas.

\begin{tabular}{|c|c|c|c|c|c|c|c|c|c|}
\hline \multirow[t]{2}{*}{ Samples ${ }^{(1)}$} & $\mathrm{pH}$ & $\mathrm{OM}^{(2)}$ & $\mathrm{H}+\mathrm{Al}$ & $\mathrm{Ca}$ & $\mathrm{Mg}$ & $\mathrm{P}$ & $\mathrm{K}$ & $\mathrm{Fe}$ & $\mathrm{Zn}$ \\
\hline & $\mathrm{H}_{2} \mathrm{O}$ & $\mathrm{g} \mathrm{kg}^{-1}$ & \multicolumn{3}{|c|}{$-\mathrm{cmol}_{\mathrm{c}} \mathrm{kg}^{-1}-$} & \multicolumn{4}{|c|}{$\longrightarrow \mathrm{mg} \mathrm{kg}^{-1}$} \\
\hline \multicolumn{10}{|c|}{ Components } \\
\hline Clay soil & 5.1 & 8.3 & 0.11 & 838 & 235 & 2.4 & 24 & 137 & 1.5 \\
\hline Sand & 6.8 & 0.4 & 0 & 115 & 7 & 7.8 & 17 & 29 & 5.5 \\
\hline Manure & 6.4 & 50.6 & 0 & 3340 & 372 & 2915 & 1076 & 81 & 52.9 \\
\hline Charcoal & 4.4 & 179 & 2.68 & 3245 & 334 & 35.5 & 510 & 10 & 7.9 \\
\hline \multicolumn{10}{|c|}{ Substrate mixtures } \\
\hline $\mathrm{S}_{\mathrm{e}}$ & 6.2 & 30.6 & 0 & 884 & 220 & 110 & 93 & 151 & 11.1 \\
\hline $\mathrm{S}$ & 5.9 & 20.0 & 0.06 & 813 & 160 & 6.0 & 33 & 138 & 5.1 \\
\hline $\mathrm{S}_{1 \mathrm{c}}$ & 5.4 & 16.4 & 0.06 & 411 & 112 & 3.2 & 51 & 117 & 4.8 \\
\hline $\mathrm{S}_{2 \mathrm{c}}$ & 6.0 & 25.1 & 0.08 & 472 & 138 & 5.4 & 47 & 134 & 4.4 \\
\hline $\mathrm{S}_{3 \mathrm{c}}$ & 5.6 & 27.3 & 0.14 & 770 & 174 & 15.6 & 102 & 112 & 6.2 \\
\hline
\end{tabular}

(1) $\mathrm{S}_{\mathrm{e}}=$ clay soil, sand and cattle manure $(3: 2: 0.5), \mathrm{S}=$ clay soil and sand $(3: 2), \mathrm{S}_{1 \mathrm{c}}=$ clay soil, sand and charcoal $(5.5: 3.5: 1), \mathrm{S}_{2 \mathrm{c}}=$ clay soil, sand and charcoal $(2.5: 2: 1), \mathrm{S}_{3 \mathrm{c}}=$ clay soil, sand and charcoal $(1.5: 2: 1),{ }^{(2)} \mathrm{OM}=$ Organic matter. 
Table 3 - Effect of substrate on quality parameters of legume tree seedlings. ${ }^{(1)}$

Tabela 3 - Efeito do substrato sobre parâmetros de avaliação da qualidade de mudas de leguminosas arbóreas. ${ }^{(1)}$

\begin{tabular}{|c|c|c|c|c|c|c|}
\hline \multirow[t]{2}{*}{$\overline{S . V .(2)}$} & \multirow{2}{*}{$\begin{array}{c}\mathrm{H}^{(3)} \\
(\mathrm{cm})\end{array}$} & \multirow{2}{*}{$\begin{array}{c}\mathrm{D}^{(4)} \\
(\mathrm{mm})\end{array}$} & $\mathrm{SDW}^{(5)}$ & $\mathrm{RDW}^{(6)}$ & \multirow[t]{2}{*}{$\mathrm{SDW} / \mathrm{RDW}^{(7)}$} & \multirow[t]{2}{*}{$\mathrm{DQI}^{(8)}$} \\
\hline & & & \multicolumn{2}{|c|}{ (g) } & & \\
\hline \multicolumn{7}{|c|}{ Inga edulis } \\
\hline $\mathrm{S}_{\mathrm{e}}$ & $30.2 \mathrm{a}$ & $4.1 \mathrm{a}$ & $3.01 \mathrm{a}$ & $0.97 \mathrm{a}$ & $3.02 \mathrm{a}$ & $0.38 \mathrm{a}$ \\
\hline$\stackrel{\mathrm{e}}{\mathrm{S}}$ & $29.2 \mathrm{a}$ & $4.0 \mathrm{a}$ & $3.10 \mathrm{a}$ & $0.97 \mathrm{a}$ & $3.43 \mathrm{a}$ & $0.39 \mathrm{a}$ \\
\hline $\mathrm{S}_{1 \mathrm{c}}$ & $28.2 \mathrm{a}$ & $3.9 \mathrm{a}$ & $3.40 \mathrm{a}$ & $0.96 \mathrm{a}$ & $3.57 \mathrm{a}$ & $0.40 \mathrm{a}$ \\
\hline $\mathrm{S}_{2 \mathrm{c}}$ & $28.3 \mathrm{a}$ & $3.8 \mathrm{a}$ & $3.30 \mathrm{a}$ & $0.91 \mathrm{a}$ & $3.79 \mathrm{a}$ & $0.38 \mathrm{a}$ \\
\hline $\mathrm{S}_{3 \mathrm{c}}$ & $27.4 \mathrm{a}$ & $3.7 \mathrm{a}$ & $3.15 \mathrm{a}$ & $1.17 \mathrm{a}$ & $2.71 \mathrm{a}$ & $0.43 \mathrm{a}$ \\
\hline$\overline{\mathrm{CV}(\%)}$ & 19.73 & 13.45 & 32.32 & 28.74 & 29.91 & 29.68 \\
\hline $\mathrm{F}$ test & $0.36 \mathrm{~ns}$ & $1.28 \mathrm{~ns}$ & $0.22 \mathrm{~ns}$ & $1.17 \mathrm{~ns}$ & $2.55 \mathrm{~ns}$ & $0.35 \mathrm{~ns}$ \\
\hline \multicolumn{7}{|c|}{ Enterolobium schomburgkii } \\
\hline $\mathrm{S}_{\mathrm{e}}$ & $9.6 \mathrm{~b}$ & $1.6 \mathrm{c}$ & $0.37 \mathrm{c}$ & $0.22 \mathrm{~b}$ & $1.91 \mathrm{ab}$ & $0.08 \mathrm{~b}$ \\
\hline $\mathrm{s}$ & $24.4 \mathrm{a}$ & $3.2 \mathrm{a}$ & $2.29 \mathrm{a}$ & $0.92 \mathrm{a}$ & $2.66 \mathrm{a}$ & $0.32 \mathrm{a}$ \\
\hline $\mathrm{S}_{\mathrm{lc}}$ & $19.6 \mathrm{a}$ & $2.8 \mathrm{ab}$ & $1.50 \mathrm{~b}$ & $1.04 \mathrm{a}$ & $1.48 \mathrm{~b}$ & $0.30 \mathrm{a}$ \\
\hline $\mathrm{S}_{2 \mathrm{c}}$ & $19.8 \mathrm{a}$ & $2.7 \mathrm{ab}$ & $1.88 \mathrm{ab}$ & $0.87 \mathrm{a}$ & $2.25 \mathrm{ab}$ & $0.29 \mathrm{a}$ \\
\hline $\mathrm{S}_{3 \mathrm{c}}$ & $18.9 \mathrm{a}$ & $2.6 \mathrm{~b}$ & $1.79 \mathrm{ab}$ & $0.78 \mathrm{a}$ & $2.34 \mathrm{ab}$ & $0.27 \mathrm{a}$ \\
\hline CV (\%) & 24.46 & 15.64 & 36.16 & 34.55 & 35.84 & 34.75 \\
\hline $\mathrm{F}$ test & $14.38 *$ & $21.21 *$ & $16.49 *$ & $14.69 *$ & $3.49 *$ & $12.17 *$ \\
\hline \multicolumn{7}{|c|}{ Clitoria fairchildiana } \\
\hline $\mathrm{S}_{\mathrm{e}}$ & $35.4 \mathrm{a}$ & $4.4 \mathrm{a}$ & $2.66 \mathrm{a}$ & $1.04 \mathrm{a}$ & $2.93 \mathrm{a}$ & $0.34 \mathrm{a}$ \\
\hline $\mathrm{S}$ & $34.6 \mathrm{a}$ & $4.5 \mathrm{a}$ & $2.41 \mathrm{a}$ & $0.90 \mathrm{a}$ & $2.73 \mathrm{a}$ & $0.32 \mathrm{a}$ \\
\hline $\mathrm{S}_{\mathrm{lc}}$ & $34.7 \mathrm{a}$ & $4.6 \mathrm{a}$ & $3.10 \mathrm{a}$ & $1.20 \mathrm{a}$ & $2.73 \mathrm{a}$ & $0.42 \mathrm{a}$ \\
\hline $\mathrm{S}_{2 \mathrm{c}}$ & $35.1 \mathrm{a}$ & $4.5 \mathrm{a}$ & $3.33 \mathrm{a}$ & $1.19 \mathrm{a}$ & $2.91 \mathrm{a}$ & $0.43 \mathrm{a}$ \\
\hline $\mathrm{S}_{3 \mathrm{c}}$ & $34.9 \mathrm{a}$ & $4.4 \mathrm{a}$ & $2.64 \mathrm{a}$ & $1.01 \mathrm{a}$ & $2.51 \mathrm{a}$ & $0.34 \mathrm{a}$ \\
\hline$\overline{C V}(\%)$ & 14.71 & 10.00 & 31.13 & 28.74 & 29.35 & 26.65 \\
\hline $\mathrm{F}$ test & $0.05 \mathrm{~ns}$ & $0.23 \mathrm{~ns}$ & $1.79 \mathrm{~ns}$ & $1.63 \mathrm{~ns}$ & $0.31 \mathrm{~ns}$ & $2.52 \mathrm{~ns}$ \\
\hline
\end{tabular}

(1) Means followed by the same letter in columns do not differ by the Tukey test at a probability of $5 \%(\mathrm{P}<0.05), \mathrm{ns}=\mathrm{not}$ significant, Inga edulis, Enterolobium shomburkii and Clitoria fairchildiana were harvested, respectively, 92 and 175 days after thinning and Clitoria fairchildiana 90 days after sowing. ${ }^{(2)} \mathrm{S} . \mathrm{V}$. = Source of variation; $\mathrm{S}_{\mathrm{e}}=$ clay soil, sand and cattle manure $(3: 2: 0.5) ; \mathrm{S}=$ clay soil and sand $(3: 2) ; \mathrm{S}_{1 \mathrm{c}}=$ clay soil, sand and charcoal $(5.5: 3.5: 1) ; \mathrm{S}_{2 \mathrm{c}}=$ clay soil, sand and charcoal $(2.5: 2: 1) ; \mathrm{S}_{3 \mathrm{c}}=$ clay soil, sand and charcoal $(1.5: 2: 1)$; ${ }^{(3)} \mathrm{H}=$ Height; ${ }^{(4)} \mathrm{D}=$ Root collar diameter; ${ }^{(5)} \mathrm{SDW}=$ Shoot dry weight; ${ }^{(6)} \mathrm{RDW}=$ Root dry weight; ${ }^{(7)} \mathrm{SDW} / \mathrm{RDW}=$ ratio shoot dry weight by root dry weight; ${ }^{(8)} \mathrm{DQI}=$ Dickson quality index.

The development of ice-cream bean seedlings in $\mathrm{S}_{\mathrm{e}}$ in comparison with the charcoal-containing substrates was not favorable for nodule formation, which was evaluated by the nodule number (NN) and nodule dry weight (NDW) (Table 4). Thus, in S and all mixtures with charcoal, the NN of ice-cream-bean was significantly higher $(\mathrm{P}<0.05)$ than in $\mathrm{S}_{\mathrm{e}}$. On the other hand, for the seedlings grown in $\mathrm{S}_{1 \mathrm{c}}$ and $\mathrm{S}_{2 \mathrm{c}}$, NDW was also significantly higher than that of seedlings developed in $\mathrm{S}_{\mathrm{e}}$. Without significant differences, the mean leaf $\mathrm{N}$ content and shoot $\mathrm{N}$ accumulation of ice-cream-bean seedlings was $34.7 \mathrm{~g} \mathrm{~kg}^{-1}$ and $91.3 \mathrm{mg}$ plant ${ }^{-1}$, respectively.

The species orelha-de-macaco was more sensitive than ice-cream-bean to charcoal addition and formed no nodules in the substrate with manure, under the experimental conditions (Table 4 ). The NN on orelhade-macaco roots was higher in $\mathrm{S}$ than in the mixture with the lowest charcoal rate, $\mathrm{S}_{1 \mathrm{c}}$. The evaluation of NDW in orelha-de-macaco showed that the nodular growth of seedlings grown in $\mathrm{S}, \mathrm{S}_{2 \mathrm{c}}$ and $\mathrm{S}_{3 \mathrm{c}}$ was significantly higher than in $\mathrm{S}_{1 \mathrm{c}}$.

In general, in comparison with orelha-de-macaco, the rapid growth and high $\mathrm{N}$ accumulation in the biomass of ice-cream-bean and palheteira plants, regardless of the substrate tested, indicated great robustness. This hardiness of ice-cream-bean and palheteira in response to the substrates with lower nutrient availability may be explained by an investment of the plants in nodulation, maintaining the $\mathrm{N}$ content unchanged.

\section{DISCUSSION}

Charcoal and bovine manure contain more nutrients than sand and clay soil. However, there are important differences between charcoal and manure, which can 
Table 4 - Effect of substrate on nodulation and nitrogen content of legume tree seedlings. ${ }^{(1)}$

Tabela 4 - Efeito do substrato sobre a nodulação e teor de nitrogênio de mudas leguminosas arbóreas. ${ }^{(1)}$

\begin{tabular}{|c|c|c|c|c|}
\hline \multirow[t]{2}{*}{ S.V..$^{(2)}$} & \multirow[t]{2}{*}{$\mathrm{NN}^{(3)}$} & $\mathrm{NDW}^{(4)}$ & Leaf $\mathrm{N}$ & $\mathrm{CNPS}^{(5)}$ \\
\hline & & (mg) & $\left(\mathrm{g} \mathrm{kg}^{-1}\right)$ & $\left(\mathrm{mg} \mathrm{plant}^{-1}\right)$ \\
\hline \multicolumn{5}{|c|}{ Inga edulis } \\
\hline $\mathrm{Se}$ & $44 \mathrm{~b}$ & $46 \mathrm{~b}$ & $35.99 \mathrm{a}$ & $104.11 \mathrm{a}$ \\
\hline $\mathrm{S}$ & $101 \mathrm{a}$ & $89 \mathrm{ab}$ & $32.88 \mathrm{a}$ & $74.84 \mathrm{a}$ \\
\hline S1c & $97 \mathrm{a}$ & $104 \mathrm{a}$ & $35.30 \mathrm{a}$ & $102.48 \mathrm{a}$ \\
\hline $\mathrm{S} 2 \mathrm{c}$ & $104 \mathrm{a}$ & $114 \mathrm{a}$ & $34.93 \mathrm{a}$ & $89.09 \mathrm{a}$ \\
\hline $\mathrm{S} 3 \mathrm{c}$ & $83 \mathrm{a}$ & $74 \mathrm{ab}$ & $34.53 \mathrm{a}$ & $85.74 \mathrm{a}$ \\
\hline $\mathrm{CV}(\%)$ & 34.37 & 25.69 & 8.20 & 17.83 \\
\hline $\mathrm{F}$ test & $5.18 *$ & $4.29 *$ & $0.66 \mathrm{~ns}$ & $2.25 \mathrm{~ns}$ \\
\hline \multicolumn{5}{|c|}{ Enterolobium schomburgkii } \\
\hline $\mathrm{Se}$ & $0 \mathrm{c}$ & $0 \mathrm{c}$ & $22.04 \mathrm{a}$ & $11.41 \mathrm{c}$ \\
\hline $\mathrm{S}$ & $28 \mathrm{a}$ & $46 \mathrm{a}$ & $22.96 \mathrm{a}$ & $52.40 \mathrm{a}$ \\
\hline S1c & $8 \mathrm{~b}$ & $13 \mathrm{bc}$ & $21.97 \mathrm{a}$ & $33.30 \mathrm{~b}$ \\
\hline $\mathrm{S} 2 \mathrm{c}$ & $17 \mathrm{ab}$ & $44 \mathrm{a}$ & $22.80 \mathrm{a}$ & $42.76 \mathrm{ab}$ \\
\hline $\mathrm{S} 3 \mathrm{c}$ & $14 \mathrm{ab}$ & $38 \mathrm{ab}$ & $22.12 \mathrm{a}$ & $46.94 \mathrm{ab}$ \\
\hline$\overline{\mathrm{CV}(\%)}$ & 65.08 & 29.48 & 11.91 & 19.94 \\
\hline $\mathrm{F}$ test & $9.87 *$ & $10.46 *$ & $0.87 \mathrm{~ns}$ & $18.69 *$ \\
\hline \multicolumn{5}{|c|}{ Clitoria fairchildiana } \\
\hline $\mathrm{Se}$ & $20 \mathrm{a}$ & $13 \mathrm{~b}$ & $33.74 \mathrm{a}$ & $54.39 \mathrm{ab}$ \\
\hline $\mathrm{S}$ & $33 \mathrm{a}$ & $44 \mathrm{a}$ & $33.90 \mathrm{a}$ & $53.25 \mathrm{~b}$ \\
\hline S1c & $32 \mathrm{a}$ & $44 \mathrm{a}$ & $34.41 \mathrm{a}$ & $67.61 \mathrm{ab}$ \\
\hline $\mathrm{S} 2 \mathrm{c}$ & $32 \mathrm{a}$ & $51 \mathrm{a}$ & $31.75 \mathrm{a}$ & $58.53 \mathrm{ab}$ \\
\hline $\mathrm{S} 3 \mathrm{c}$ & $33 \mathrm{a}$ & $50 \mathrm{a}$ & $34.72 \mathrm{a}$ & $70.30 \mathrm{a}$ \\
\hline$\overline{\mathrm{CV}(\%)}$ & 35.44 & 25.20 & 7.89 & 12.41 \\
\hline $\mathrm{F}$ test & $1.14 \mathrm{~ns}$ & $5.79 *$ & $0.77 \mathrm{~ns}$ & $4.51 *$ \\
\hline
\end{tabular}

${ }^{(1)}$ Means followed by the same letter in columns do not differ by the Tukey test at a probability of $5 \%(\mathrm{P}<0.05)$, ns $=$ not significant, Inga edulis, Enterolobium schomburkii were harvested, respectively, 92 and 175 days after thinning and Clitoria fairchildiana 90 days after sowing. (2) S.V. = Source of variation; $\mathrm{S}_{\mathrm{e}}=$ clay soil, sand and cattle manure $(3: 2: 0.5) ; \mathrm{S}=$ clay soil and sand $(3: 2) ; \mathrm{S}_{1 \mathrm{c}}=$ clay soil, sand and charcoal $(5.5: 3.5: 1) ; \mathrm{S}_{2 \mathrm{c}}=$ clay soil, sand and charcoal $(2.5: 2: 1) ; \mathrm{S}_{3 \mathrm{c}}=$ clay soil, sand and charcoal $(1.5: 2: 1) ;{ }^{(3)}$ Nodule number; ${ }^{(4)} \mathrm{NDW}=$ Nodule dry weight; ${ }^{(5)} \mathrm{CNPS}=$ Cumulative $\mathrm{N}$ in plant shoots.

lead to different results in seedling production. In the case studied, the organic matter (OM) content of charcoal was 3.5 times higher than that of manure, while the $\mathrm{Ca}$ and $\mathrm{Mg}$ contents were similar as in manure. Under the tested conditions, the $\mathrm{P}, \mathrm{K}, \mathrm{Fe}$ and $\mathrm{Zn}$ contents in manure were far higher than in charcoal, particularly with regard to the available $\mathrm{P}$ content. The results confirmed that the key contribution of charcoal to an improved substrate quality are not the chemical characteristics, but the potential to enhance the physical parameters of the substrate by raising the $\mathrm{OM}$ content and by improving porosity and water retention of the substrate (TRYON, 1948; ZANETTI et al., 2003). However, the physical quality of the substrates was not analyzed in this study.

The chemical analysis of the substrate clearly showed that charcoal addition reduced the availability of most nutrients and of $\mathrm{OM}$, and that the $\mathrm{pH}$ became more acidic than in $\mathrm{S}_{\mathrm{e}}$ (Table 2). Moreover, the $\mathrm{P}$ contents in $\mathrm{S}_{\mathrm{e}}\left(110.1 \mathrm{mg} \mathrm{kg}^{-1}\right)$ were in the mean 10 times higher than the $\mathrm{P}$ content in the substrates with charcoal, where the availability of this element was highest in $\mathrm{S}_{3 \mathrm{c}}\left(15.6 \mathrm{mg} \mathrm{kg}^{-1}\right)$. In this substrate with highest charcoal content, the contents of $\mathrm{OM}, \mathrm{Ca}, \mathrm{Mg}$, and Fe were similar to those of $\mathrm{S}_{\mathrm{e}}$, while the $\mathrm{K}$ content was higher than in $\mathrm{S}_{\mathrm{e}}$, indicating that charcoal provides high amounts of this essential element. In addition, $\mathrm{S}_{3 \mathrm{c}}$ stood out among the substrates with charcoal and in comparison with S with higher contents of OM, Mg, P, K, Zn, and $\mathrm{Mn}$. The improvements in the chemical properties of the substrates due to the effect of charcoal addition observed in this study were inferior to those described by Tryon (1948) and Chidumayo (1994), who reported that the $\mathrm{pH}$ was neutralized by increasing the charcoal rates (Table 2). Therefore, when adding charcoal to substrates, the variation in $\mathrm{pH}$ and nutrient contents

Revista Árvore, Viçosa-MG, v.40, n.6, p.1049-1058, 2016 
according to the species or species mixture used for wood carbonization should be taken into account (SANTOS et al., 2013)

The results in seedling quality were also lower than expected, since Souchie et al. (2011) observed improvements directly proportional to the increase of charcoal in the substrate of Tachigali vulgaris, while in this experiment the improvement in the seedling quality did not accompany the increase of charcoal in the substrate.

The larger seed size may have been responsible for the lower plasticity of response to the substrates of ice-cream-bean and palheteira compared to orelhade-macaco plants (Table 3 ), by providing greater independence due to the accumulated reserves in a larger seed (UCHIDA; CAMPOS, 2000).

At the time of harvest, the seedlings of the species under study had a taller mean height (Table 3 ) than the minimum height of 15 to $30 \mathrm{~cm}$, recommended by Gomes and Paiva (2006), except for the orelha-de-macaco plants in $\mathrm{S}_{\mathrm{e}}$. Palheteira plants had a taller mean height than the $20.4 \mathrm{~cm}$ reported for this spescies in a study of Portela et al. (2001), 150 days after sowing on substrate with $50 \%$ soil and $50 \%$ urban waste compost. On the other hand, in a study of Souza et al. (2007), palheteira plants had a height of $42.2 \mathrm{~cm}$ and a diameter of 9.1 $\mathrm{mm}, 70$ days after transplanting. These values exceeded the values of this experiment, where the mean height was $35.4 \mathrm{~cm}$ in $\mathrm{S}_{\mathrm{e}}$ and the mean root collar diameter $4.6 \mathrm{~mm}$ in $\mathrm{S}_{1 \mathrm{c}}$.

According to Gomes and Paiva (2006), the lower the SDW/RDW ratio, the better the plant quality. In this experiment, the means of ice-cream-bean, orelhade-macaco and palheteira plants had lower SDW/RDW ratios than the 1.66 of the palheteira saplings cultivated in agricultural soil by Souza et al. (2007).

At harvest, the DQI of most plants of the three species under study was higher than the minimum required for field planting, except in the case of orelhade-macaco in $\mathrm{S}_{\mathrm{e}}$. According to Hunt (1990), and cited by Chaves and Paiva (2004), 0.20 is the minimum DQI recommended for Picea abies and Pseudotsuga menziesii seedlings

Specifically in the case of palheteira, calculating the DQI with data published by Souza et al. (2007) for seedlings cultivated in agricultural soil for 70 days, the DQI of 3.9 was almost 10 times higher than the mean DQI of 0.34 of the palheteira saplings of this experiment with ice-cream bean, orelha de macaco e palheteira. For the results of this experiment with palheteira in charcoal-enriched substrate, this also shows that after 90 days, the DQI had not reached the potential of this species. Moreover, the DQI values for palheteira found by Souza et al. (2007) also exceeded the values of ice-cream-bean and orelha-de-macaco in all treatments. Possibly, the explanation for the difference in the quality of palheteira seedlings was that Souza et al. (2007) used no restriction of the natural luminosity in the greenhouse, since a slight level of chlorosis was observed on the seedlings during the experiment.

The higher NN and NDW in ice-cream-bean and NDW in palheteira on the substrates with charcoal compared to $\mathrm{S}_{\mathrm{e}}$ were possibly a response to the lower entries of $\mathrm{N}$ in the type of organic material used in the substrate. It is known that $\mathrm{N}$ uptake in noduliferous legumes consists of the sum of $\mathrm{N}_{2}$ fixed by symbiotic processes and $\mathrm{N}$ mineralized in the soil, resulting from the decomposition of the OM pools. The evidence is that, as the $\mathrm{N}_{2}$-fixing symbiotic process is a restorative property of the ecosystem in response to disturbances and is weaker in more favorable environments, the chemical properties of charcoal stimulated nodulation more than manure.

The results of the evaluation of nodulation of the three species allows the statement that manure in the substrate composition inhibited nodulation, similarly as the symbiontic process reported by Vieira et al. (2011) was inhibited by the supply of mineral N. The full nodulation of the seedlings is interesting since under field conditions, they may be more autonomous in terms of $\mathrm{N}$ uptake.

In the case of ice-cream-bean and palheteira, the leaf $\mathrm{N}$ content in this experiment was higher than the mean reported by Souza et al (2007) for Leucaena leucocephala with $21.4 \mathrm{~g} \mathrm{~kg}^{-1}$, and similar to the mean of orelha-de-macaco. With regard to shoot $\mathrm{N}$ accumulation, Vieira et al (2011) reported a mean of $38.3 \mathrm{mg} \mathrm{plant}^{-1}$ for Swartzia argentea, which is lower than most values of shoot $\mathrm{N}$ content determined in ice-cream-bean, palheteira and orelha-de-macaco.

The absence of differences in growth and nodulation improvement of ice-cream-bean and palheteira plants in the charcoal-containing substrates 
suggested that charcoal could be used as a substitute for manure without affecting the seedling quality (Table 3 ). On the other hand, for orelha-de-macaco plants, the growth and nodulation traits were more favorable in $\mathrm{S}$ and $\mathrm{S}_{2 \mathrm{c}}$, also suggesting the possibility of substitution of manure by charcoal or only the omission of manure.

\section{CONCLUSION}

The growth of ice-cream-bean and palheteira seedlings was not altered and nodulation was favored by the use of charcoal as substitute of manure in the $3: 2: 0.5$ substrate of clay soil, sand and manure. In the substrates of clay soil and sand $(3: 2)$ and of clay soil, sand and charcoal $(2.5: 2: 1)$, the growth and nodulation of orelha-de-macaco seedlings was better than in the 3:2:0.5 clay soil, sand and manure mixture. Thus, the results suggest that the substitution of manure by charcoal favors the quality of the three studied species.

\section{REFERENCES}

BERNARDINO, D.C.S.; PAIVA, H.N.; NEVES, J.C.L.; GOMES, J.M.; MARQUES, V.B.

Crescimento e qualidade de mudas de Anadenanthera macrocarpa (Benth.) Brenan em resposta à saturação por bases do substrato. Revista Árvore, v.29, n.6, p.863-870, 2005.

CEnteno, A.J. Curso de estatística aplicada à biologia. Goiânia: UFG, 1990. 188 p.

CHAVES, A.S.; PAIVA, H.N. Influência de diferentes períodos de sombreamento sobre a qualidade de mudas de fedegoso (Senna macranthera (Collad.) Irwin et Barn. Scientia Forestalis, v.65, n.1, p.22-29, 2004.

CHIDUMAYO, E.N. Effects of wood carbonization on soil and initial development of seedlings in miombo woodland, Zambia. Forest Ecology and Management, v.70, n.1, p.353-357, 1994.

CUNHA, A.O.; ANDRADE, L.A.; BRUNO, R.L.A.; SILVA, J.A.L.;SOUZA, V.C. Efeitos de substratos e das dimensões dos recipientes na qualidade das mudas de Tabebuia impertiginosa (Mart. Ex D.C.) Standl. Revista Árvore, v.29, n.4, p.507-516, 2006.

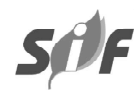

DICKSON, A.; LEAF, A.; HOSNER, J.F. Quality appraisal of white spruce and white pine seedling stock in nurseries. Forestry Chronicle, v.36, p.10-13, 1960.

\section{EMPRESA BRASILEIRA DE PESQUISA}

AGROPECUÁRIA - EMBRAPA. Manual de métodos de análise de solo. Rio de Janeiro: Centro Nacional de Pesquisa de Solos, 1997. 212p.

FONSECA, E.P.; VALERI, S.V.; MIGLIORANZA, E.; FONSECA, N.A.N.; COUTO, L. Padrão de qualidade de mudas de Trema micrantha (L.) Blume, produzidas sob diferentes períodos de sombreamento. Revista Árvore, v.26, n.4, p.515-523, 2002.

GLASER, B.; HAUMAIER, L.; GUGGENBERGER, G.; ZECH, W. The Terra Preta phenomenon - a model for sustainable agriculture in the humid tropics. Naturwissenschaften, v. 88 , n. 1 , p.37-41, 2001 .

GOMES, J.M.; PAIVA, H.N. Viveiros

florestais. Viçosa, MG: Universidade Federal de Viçosa, 2006. 116p.

HUNGRIA, M. Coleta de nódulos e isolamento de rizóbios. In: HUNGRIA, M.; ARAÚJO, R.S. (Ed.) Manual de métodos empregados em estudos de microbiologia agrícola. Brasília: Empresa Brasileira de Pesquisa Agropecuária, 1994. p.45-59.

\section{INSTITUTO NACIONAL DE PESQUISAS}

ESPACIAIS - INPE. [acessado em: jan. 28, 2013]. Disponível em: http:/www. Cptec.inpe.br/clima/ monit/monitor_brasil.shtml

LORENZI, H. Árvores brasileiras. Nova Odessa: Instituto Plantarum, 2002. 381p.

MAJOR,J.; DITOMMASO, A.; LEHMANN, J.; FALCÃO, N.P.S. Weed dynamics on Amazonian Dark Earth and adjacent soils of Brazil.

Agriculture, Ecosystems and Environment, v. 11, p.1-12, 2005.

MENDONÇA, E.S.; MATOS, E.S. Matéria orgânica do solo: Método de análises. Viçosa, MG: Universidade Federal de Viçosa, 2005.107p.

Revista Árvore, Viçosa-MG, v.40, n.6, p.1049-1058, 2016 
MOREIRA, A. Fertilidade, matéria orgânica e substâncias húmicas em solos antropogênicos da Amazônia Ocidental. Bragantia, v.66, p.307315, 2007.

OLIVEIRA, D.M.; FALCÃO, N.P.S.; SOUZA, L.A.G. Efeito do resíduo de carvão vegetal e pó de serra no crescimento vegetativo e na nodulação do feijão caupi (Vigna Unguiculata L. Walp) em Latossolo Amarelo distrófico da Amazônia Central. In: REUNIÃO CIENTÍFICA DA REDE CTPETRO AMAZÔNIA, 3., 2010, Manaus. Anais... Manaus: Instituto Nacional de Pesquisas da Amazônia, 2010. p.1-11.

PORTELA, R.C.Q.; SILVA, I.L.; PINÃRODRIGUES, F.C.M. Crescimento inicial de mudas de Clitoria fairchildiana Howard e Peltophorum dubium (Sprenge) Taub em diferentes condições de sombreamento. Ciência Florestal, v.11, n.2, p.163-170, 2001.

RONDON, M.A., LEHMANN, J.; RAMÍREZ, J.; HURTADO, M. Biological nitrogen fixation by common beans (Phaseolus vulgaris L.) increases with bio-char additions. Biology Fertility Soils, v.43, p.699-708, 2007.

SANTOS, R.C.; CARNEIRO, A.C.O.; PIMENTA, A.S.; CASTRO, R.V.O.; MARINHO, I.V.; TRUGILHO, P.F.; ALVES, I.C.N.; CASTRO, A.F.N.M. Potencial energético da madeira de espécies oriundas de plano de manejo florestal no estado do Rio Grande do Norte. Ciência Florestal, v.23, n.2, p.491-502, 2013

SCHUMACHER, M.V.; CALDEIRA, M.V.W.; OLIVEIRA, E.R.V.; PIROLI, E.L. Influência do vermicomposto na produção de mudas de
Eucalyptus grandis hillex maiden. Ciência Florestal, v. 11, n.2, p.121-130, 2001.

SOUCHIE, F.F.; MARIMON JUNIOR, B.H.; PETTER, F.A.; MADARI, B.E.; MARIMON, B.S.; LENZA, E. Carvão pirogênico como condicionante para substrato de mudas de Tachigali vulgaris L.G.Silva \& H.C.Lima. Ciência Florestal, v.21, n.4, p. 811-821, 2011.

SOUZA, L.A.G.; BEZERRA NETO, E.; SANTOS, C.E.R.S.; STAMFORD, N.P. Desenvolvimento e nodulação natural de leguminosas arbóreas em solos de Pernambuco. Pesquisa

Agropecuária Brasileira, v.42, n.2, p.207:217, 2007.

TRYON, E.H. Effect of charcoal on certain physical, chemical, and biological properties of forest soils. Ecological Monographs, v. 18, n.1, p.81-115, 1948.

UCHIDA, T.; CAMPOS, M.A.A. Influência do sombreamento no crescimento de mudas de cumaru (Dipteryx odorata (Aubl.) Willd. Fabaceae), cultivadas em viveiro. Acta Amazônica, v.30, n.1, p.107-114, 2000.

VIEIRA, E.P.; SOUZA, L.A.G. Inoculação com rizóbios em mudas de acapu do igapó e saboarana. Revista de Ciências Agrárias, v.54, n. 1, p.54-62, 2011.

ZANETTI, M.; CAZETTA, J.O.; MATTOS JUNIOR, D.; CARVALHO, S.A. Uso de subprodutos de carvão vegetal na formação de porta-enxerto limoeiro 'cravo' em ambiente protegido. Revista Brasileira de Fruticultura, v.25, n.3, p.508-512, 2003. 